\title{
ANTI-Yersinia enterocolitica SEROTYPE 3 AGGLUTININS IN SWINE SERA FROM RIO DE JANEIRO ${ }^{1}$
}

\author{
Norma dos Santos Lázaro ${ }^{2}$ and Ernesto Hofer $^{3}$
}

\begin{abstract}
Lázaro N.S. \& Hofer E. 1996. Anti-Yersinia enterocolitica serotype 3 agglutinins in swine sera from Rio de Janeiro. Pesquisa Veterinária Brasileira 16(4):121-123. Depto Epidemiologia e Saúde Pública, Instituto de Veterinária, Universidade Federal Rural do Rio de Janeiro, Seropédica, RJ 23851-970, Brasil.

The slow serum agglutination test was applied to 119 healthy pigs for the determination of the possible presence of anti-Yersinia enterocolitica 0:3 agglutinins. Of the $63.9 \%$ reactive animals $(>1: 20), 8.4 \%$ presented positive titers $(>1: 80)$, suggesting the presence of this pathogen among swine and consequently an additional public health problem.
\end{abstract}

INDEX TERMS: Yersinia enterocolitica, agglutinins, swine.

SINOPSE.- Aglutininas anti-Yersinia enterocolitica 0:3 em soros de suínos do Rio de Janeiro. A pesquisa de aglutininas antiYersinia enterocolitica 0:3 foi realizada em 119 suínos sadios, através da prova de soro-aglutinação lenta. Dos $63,9 \%$ animais reagentes $(>1: 20), 8,4 \%$ apresentaram títulos a nível de positivo $(>1: 80)$ sugerindo a presença deste patógeno em nossos rebanhos suínos constituindo-se consequentemente em mais um problema de saúde pública.

TERMOS DE INDEXAÇÃO: Yersinia enterocolitica, aglutininas, suíno.

\section{INTRODUCTION}

Infection with Yersinia enterocolitica causes several clinical problems in swine, with aggression mainly at the enteric level, although a less frequent occurrence of extraintestinal infection has also been reported (Ahvonen et al. 1973). An important feature observed in swine is the marked occurrence of asymptomatic carriers (Mollaret et al. 1979, Hurvell 1981, Adesiyun et al. 1992), with significant isolation of $Y$. enterocolitica in some European countries (Pedersen 1976, Wuthe et al. 1982), Japan (Zen-Yoji 1981), Canada (Schiemann \& Fleming 1981) and Brazil (Falcão 1981, Castro et al. 1983,

\footnotetext{
${ }^{1}$ Accepted for publication on September 24, 1996.

${ }^{2}$ Departamento de Epidemiologia e Saúde Pública, Instituto de Veterinária, Universidade Federal Rural do Rio de Janeiro, Seropédica, RJ 23851970, Brazil.

${ }^{3}$ Departamento de Bacteriologia, Instituto Oswaldo Cruz, Rio de Janeiro, RJ, 21045-900, Brazil.
}

Lázaro et al. 1986, Mendonça et al. 1992, 1995). The strains isolated from swine usually belong to the serotypes responsible for human enteritis, 0:3 in particular. In view of the lack of reports on this subject in the Brazilian literature, and on the basis of the notifications of isolation of this microorganism in our country, the objective of the present study was to determine the frequency of $Y$. enterocolitica 0:3 dissemination among Brazilian swine by searching for circulating agglutinins through the slow serum agglutination test.

\section{MATERIALS AND METHODS}

Sampling

We used 119 healthy pigs of different age ranges originating from twelve properties in the municipal districts of Itaguaí, Seropédica and Santa Cruz, in the state of Rio de Janeiro, Brazil. The meat was produced for domestic consumption and for sale on the street. Blood samples $(5 \mathrm{ml})$ were obtained by puncture of the marginal vein of the ear and sera were inactivated at $56^{\circ} \mathrm{C}$ for 30 minutes in a water bath and stored at $-20^{\circ} \mathrm{C}$ until the time for use.

\section{Y. enterocolitica antigen}

The strain used was M.y1, biotype 4, serotype 3 and phagotype VIII from the M.Y. (Malmo Yersinia enterocolitica) collection, kindly provided by Prof. S. Winblad, Institute of Clinical Bacteriology, Malmo, Sweden.

Antigen was obtained by the method of Hofer (see Lázaro 1980). The strain was cultured on Agar Mueller-Hinton 
medium (DIFCO) and incubated at $25^{\circ} \mathrm{C}$ for 24 to 48 hours. The growth suspension was obtained with saline containing $0.2 \mathrm{~g} \%$ 2-3-5 triphenyltetrazolium chloride (TTC-Difco) and incubated at $37^{\circ} \mathrm{C}$ for 4 to 6 hours, the time needed for TTC reduction to formazan (demonstrated by the development of red color). The suspension was then washed three times in saline by centrifugation at $3000 \mathrm{rpm}$ for 20 minutes. Ten $\mathrm{ml}$ of a solution of $1 \mathrm{ml}$ glycerol p.a., $1 \mathrm{ml}$ liquid phenol p.a. and $98 \mathrm{ml} 0.9 \%$ saline sterilized at $121^{\circ} \mathrm{C}$ for 30 minutes were added to the colored deposit. At the time of use, the preparation was diluted in $0.3 \mathrm{~g} \%$ phenol-saline so as to obtain turbidity corresponding to tube 2 of the nephelometer of McFarland $\left(6 \times 10^{8}\right.$ bacteria/ml). The original suspension is stable for up to 3 months when stored at $4-8^{\circ} \mathrm{C}$.

\section{Slow serum agglutination test}

A few assays were first performed in order to obtain a sufficiently stable standardized technique for the detection of anti-Yersinia enterocolitica 0:3 agglutinins, with special emphasis on parameters such as temperature and time of exposure to the antigen-antibody pair. Specific somatic antisera obtained from rabbits immunized with standard strains were used, with titers ranging from 1:640 to 1:2,560.

In the tube agglutination test, swine sera were diluted and supplemented with antigens at final titers of 1:20, 1:40, $1: 80$ and so forth. The material was incubated in a water bath for 2 hours at $50^{\circ} \mathrm{C}$ and then for 22 hours at $37^{\circ} \mathrm{C}$.

The choice of an agglutinating titer to be considered as a reference point characterizing the possible states of infection/ disease in swine was based on the observations of Winblad (1968), Ahvonen \& Sievers (1969) and Wauters (1970), who adopted a titer of $1: 80$ as the initial mark of positivity for the serologic diagnosis in humans.

\section{RESULTS AND DISCUSSION}

The results presented in Table 1 show that 76 (63.9\%) of the 119 pigs analyzed were sensitized to $Y$. enterocolitica, with titers ${ }^{3} 1: 20$, although only $20(8.4 \%)$ were positive, presenting titers ${ }^{31}$ :80 (Table 2).

Analysis of the individual behavior of each serum sample in the presence of the Yersinia enterocolitica 0:3 antigen showed that some animals reacted with high titers and could therefore

Table 1. Frequency of seroreacting ( $\square$ 1:20) to Yersinia enterocolitica serotype 3 of the 119 swine

\begin{tabular}{ccc}
\hline \multirow{2}{*}{ Titers } & \multicolumn{2}{c}{ Seroreacting } \\
\cline { 2 - 3 } & $\mathrm{n}$ & $\%$ \\
\hline 20 & 38 & 31.9 \\
40 & 28 & 23.5 \\
80 & 05 & 4.2 \\
160 & 02 & 1.7 \\
320 & 03 & 2.5 \\
Total & 76 & 63.9 \\
\hline
\end{tabular}

$\mathrm{n}=$ number of swine.

\begin{tabular}{|c|c|c|}
\hline \multirow[t]{2}{*}{ Titers } & \multicolumn{2}{|c|}{ Seropositive } \\
\hline & $\mathrm{n}$ & $\%$ \\
\hline 80 & 05 & 4.2 \\
\hline 160 & 02 & 1.7 \\
\hline 320 & 03 & 2.5 \\
\hline Total & 10 & 8.4 \\
\hline
\end{tabular}

be considered to be in a state of infection and/or disease due to this serotype, or, to a lesser extent, due to a serotype related to it. It should be pointed out that, even though the prevalence of seropositive animals was low, this result confirms literature reports that swine play a relevant role in the epidemiology of infection with this serotype (Pedersen 1976, Nesbakken \& Kapperud 1985). Indeed, a strong correlation has been demonstrated between the presence of $Y$. enterocolitica 0:3 in man and in swine sharing the same geographic area (Christensen 1980, Schiemann \& Fleming 1981).

By comparing the frequency of seroreactive (63.9\%) and positive $(8.4 \%)$ animals observed in the present study with the isolation of $Y$. enterocolitica from swine reported by others, we observe that Nesbakken $(1985,1988)$ obtained $68.1 \%$ and 83.3\% positivity, respectively, Hariharam et al (1995) obtained $42.0 \%$ isolation of $Y$. enterocolitica serotype $0: 3$, although values of less than $6 \%$ have been reported by Hunter et al. (1983) and Okoroafor et al. (1988).

Data about the isolation of $Y$. enterocolitica $0: 3$ from swine in Brazil are scarce. Lázaro et al. (1986) isolated $Y$. enterocolitica serotype 3 , biotype 4 , lysotype VIII from the feces of swine with diarrhea, and Mendonça et al. (1992) obtained a 50.0\% rate of carrier swine in Rio de Janeiro.

With respect to the serologic diagnosis of infection with Y. enterocolitica, Falcão et al. (1979) analyzed 1554 sera from swine from the states of São Paulo, Parana and Santa Catarina for the presence of $Y$. enterocolitica serotypes 0:3, 0:5 and 0:9 and detected $31.3 \%$ sera reacting to one or more serotypes. Lopes \& Falcão (1980), in a study of 1,609 human sera for the presence of $Y$. enterocolitica $0: 3$, obtained $0.62 \%$ positivity, and Nattermann et al. (1986) obtained $1.4 \%$ seropositivity in a study of 3,534 swine.

According to Graux \& Wauters (1966), serodiagnosis is a highly valuable process for a late or retrospective diagnosis in familiar or epidemic cases. In the present study, we noted that the high percentage $(63.9 \%)$ of reacting swine (titer $\left.{ }^{3} 1: 20\right)$ was possibly due to the fact that these animals, at some time in their life, had been sensitized to $Y$. enterocolitica $0: 3$ or even to another closely related serotype, as deduced from the large number of sera reacting at low titers.

In this respect, Winblad \& Sternby (1966) pointed out that anti- $Y$. enterocolitica antibodies are detectable only one week after the clinical manifestations, and Schiemann (1988) did not observe a correlation between severity of the infection and antibody level in the serum of experimentally inoculated 
swine.

Although in the present study the frequency of seropositive animals was low (8.4\%), the results confirm the reports in the Brazilian literature showing that this pathogen circulates in our midst (Castro et al. 1983, Lázaro et al. 1986, Mendonça et al. 1992).

In addition, serum diagnosis may be useful as an auxiliary method in the control of this disease on rearing farms and at abattoirs and meat packing plants where swine, as well as the food obtained from them, represent an important source of infection for man.

Acknowledgements.- The authors thank Dr. Dalia dos Prazeres Rodrigues, Oswaldo Cruz Institute, Rio de Janeiro, Brazil, for their valuable assistance.

\section{REFERENCES}

Adesiyun A.A., Kaminjolo J.S., Loregnard R. \& Kitson-Piggott W. 1992. Frequency of isolation of Yersinia enterocolitica from livestock in Trinidad. Vet. Rec. 28:516

Ahvonen P., Thal E. \& Vasenius H. 1973. Occurrence of Yersinia enterocolitica in animals in Finland and Sweden. Contr. Microbiol. Immun. 2:135.

Ahvonen P. \& Sievers K. 1969. Yersinia enterocolitica infection associated with Brucella agglutinins. Clinical features of 24 patients. Acta Med. Scand. 185:121-125.

Castro A.F.P., Ricci L.C., Almeida A.C., Oliveira M.S. \& Barcellos D.E.S.H. 1983. Virulence factors of Yersinia enterocolitica isolated from pigs. Revta Microbiol. 14:48-54.

Christensen S.G. 1980. Yersinia enterocolitica in Danish pigs. J. Appl. Bacteriol. 48:377-382.

Falcão D.P. 1981. Présence de Yersinia enterocolitica et Yersinia pseudotuberculosis in Amérique Latine. Revta Microbiol. 12:5-9.

Falcão D.P., Giorgi W., Imbriani E.M.M., Pincetta L.A. \& Sentone E.H.T. 1979. Anticorpos anti-Yersinia enterocolitica em soros de suínos. X Congr. Bras. Microbiologia, Rio de Janeiro, p. 57-58. (Resumo)

Graux C. \& Wauters G. 1966. Infection familiale a Yersinia enterocolitica. Acta Clin. Belgica 21:206-215.

Hariharam H., Giles J.S., Heaney S.B., Leclerc S.M. \& Schurman R.D. 1995. Isolation, serotypes, and virulence-associated properties of Yersinia enterocolitica from the tonsils of slaughter hogs. Can. J. Vet. Res. 59:161166.

Hunter D., Hughes S. \& Fox E. 1983. Isolation of Yersinia enterocolitica from pigs in the United Kingdom. Vet. Rec. 112:322-323.

Hurvell B., 1981. Zoonotic Yersinia enterocolitica infection: Host Range, Clinical manifestations and transmission between animals and man. In: Bottone C.J. (ed.) Yersinia enterocolitica. C.R.C. Press, Florida, p. 145-159.

Lázaro N.S. 1980. Reações sorológicas cruzadas entre Yersinia enterocolitica sorotipo 9 e Brucella sp em bovinos e suínos. Tese de Mestrado, Univ. Fed. Minas Gerais, Belo Horizonte.

Lázaro N.S., Hofer E., Reyes S. \& Britto M.S.M. 1986. Infecção mista por Salmonella infantis e Yersinia enterocolitica sorotipo 03 em suíno, Rio de Janeiro. XX Congr. Bras. Med. Veterinária, Cuiabá, Mato Grosso, p. 135.
Lopes M.A. \& Falcão D.P. 1980. Aglutininas anti-Yersinia enterocolitica e antiYersinia pseudotuberculosis em soros humanos. Revta Microbiol. 11:34-40.

Mendonça C.L., Lázaro N.S., Duque V.M. \& Hofer E. 1995. Fatores de virulência em Yersinia enterocolitica 0:3 isoladas de suínos sadios, Rio de Janeiro. Pesq. Vet. Bras. 15(1):11-14.

Mendonça C.L., Lázaro N.S., Hofer E., Ernandez D. \& Duque V.M. 1992. Isolamento de Yersinia enterocolitica em suínos abatidos na cidade do Rio de Janeiro. Arqs Univ. Fed. Rural Rio de J. 15:147-154.

Mollaret H.H., Bercovier H. \& Alonso J.M. 1979. Summary of the data received at the WHO Reference Center for Yersinia enterocolitica. Contr. Microbiol. Immun. 5:174-184.

Nattermann H., Dedek J. \& Loepelmann H. 1986. Serological studies on the occurrence of Yersinia enterocolitica in wild board. Mh. Vet. Med. 41:565567.

Nesbakken T. 1985. Comparison of sampling and isolation procedures for recovery of Yersinia enterocolitica serotype 0:3 from the oral cavity of slaughter pigs. Acta Vet. Scand. 26:127-137.

Nesbakken T. 1988. Enumeration of Yersinia enterocolitica 0:3 from the porcine oral cavity and its occurrence on cut surfaces of pig carcasses and the environments in a slaughter house. Int. J. Food Microbiol. 6:287-293.

Nesbakken T. \& Kapperud G. 1985. Yersinia enterocolitica and Yersinia enterocolitica-like bacteria in Norwegian slaughter pigs. Int.J. Food Microbiol. 1:301-309.

Okoroafor E., Adesiyun A.A. \& Agbonlahor D.E. 1988. Prevalence and characteristics of Yersinia enterocolitica strains isolated from pigs in Jos, Nigeria. Brit. Vet. J. 144:131-138.

Pedersen K.B. 1976. Isolation of Yersinia enterocolitica from Danish swine and dogs. Acta Path. Microbiol. Scand. Sect. B 84:317-318.

Schiemann D.A. 1988. The pathogenicity of Yersinia enterocolitica for piglets. Can. J. Vet. Res. 52:325-330.

Schiemann D.A. \& Fleming, C.A. 1981. Yersinia enterocolitica isolated from throats of swine in eastern and western Canada. Can. J. Microbiol. 27:13261333.

Wauters G. 1970. Contribution à l'étude de Yersinia enterocolitica. Thése, Université Catholique de Louvain, Vander-éditeur, Bruxelles.

Winblad S. 1968. Studies on O-antigen factors of Yersinia enterocolitica. Int. Symp. on Pseudotuberculosis, Progr. Immunobiol. Standard, Basel, 9:337342 .

Winblad S. \& Sternby N.H. 1966. Pasteurellosis X a human enteric infection with acute terminal ileitis or mesenteric lymphadenitis. Acta Pathol. Microbiol. Scand. 66:285.

Wuthe H.H., Schulz-Lell G., Bohlck I. \& Aleksic S. 1982. Results of cultural tests on Yersinia enterocolitica in samples from men and pigs in SchleswigHolstein. Berl. Münch. Tierärztl. Wschr. 95:288-292.

Zen-Yoji H. 1981. Epidemiologic aspects of Yersiniosis in Japan, p.205-216 In: Bottone C.J. (ed.) Yersinia enterocolitica. CRC Press, Florida. 